\title{
Program Assessment and Evaluation for Continuous Quality Improvement
}

\author{
Gurram Sunitha', J Avanija ${ }^{2}$ \\ ${ }^{1}$ Professor, Department of CSE, Sree Vidyanikethan Engineering College, Tirupati, \\ ${ }^{2}$ Associate Professor, Department of CSE, Sree Vidyanikethan Engineering College, Tirupati \\ 'gurramsunitha@gmail.com \\ 3avans75@yahoo.co.in
}

\begin{abstract}
Measurement of educational system / outcomes is a very complex, tedious and rigorous process. Immeasurable educational system/outcomes, means that the educational system is not properly understood or that the measurement system is not properly defined or benchmark measurement techniques are not yet developed. If educational system and its outcomes are not properly measured, then the educational system in itself is not properly understood, the goals of educational system are vaguely set and there is no process of review and refinement of quality of educational system. The intangibles of educational system must be clearly understood, well-defined and crisply measured to achieve the goals of outcome-based education and redirect the future of educational system. Measuring scholarship of knowledge in students and academic success of institutions is the key to deliver potentially skilled graduates to the society and the nation. Measurement of outcomes of education provides reliable insights for understanding the impact of education on stakeholders. This paper presents a model for measuring outcomes attainments for oneto-many model course outcome-program outcome
\end{abstract}

\section{Gurram Sunitha}

Professor, Department of CSE, Sree Vidyanikethan Engineering College, Tirupati, gurramsunitha@gmail.com mapping and also presents a sample of how to use assessment results for continuous quality improvement.

Keywords: outcome based education, continuous quality improvement, outcomes assessment, program assessment and evaluation.

\section{Introduction}

Educational assessment or educational evaluation is the systematic process of documenting and using empirical data on the knowledge, skill, attitudes, and beliefs to refine programs and improve student learning (Allen M.J. 2004).

Assessment is the process of gathering and discussing information from multiple and diverse sources in order to develop a deep understanding of what students know, understand, and can do with their knowledge as a result of their educational experiences; the process culminates when assessment results are used to improve subsequent learning (Huba et al., 2000).

Student performance assessment is a continuous task in teaching-learning process where students are assigned a variety of tasks to execute and are keenly observed for their performance. Also, feedback is taken from potential stakeholders. The students' performance and the stakeholder feedback is well documented and analysed for understanding the strengths and weaknesses of teaching-learning 
process, diversity of talents in students, training need analysis, industry-institute gap, societal needs etc.

An educational program must be assessed continuously for improvement of instruction, curriculum etc of an educational program. By assessing the students' performance in a program and gathering needs of stakeholders, measures can be taken for continuous improvement of the educational program. Further students and faculty must prepare and implement short-term plans for quality improvement in teaching-learning process; departments and institutions must prepare short-term goals and strategic plans and execute them stringently for quality improvement in educational programs and their curriculum.

\section{Assessment and Evaluation for Continuous Quality Improvement}

Continuous Quality Improvement (CQI) is the process-based, data-driven approach for improving the quality of a product or service. Accreditation Board for Engineering and Technology (ABET) lists continuous improvement as one of the criteria for its accreditation process (ABET Accreditation 2019). It specifies that processes for program evaluation and assessment must be well-defined and scrupulously documented. The program evaluation and assessment results must be properly utilized for continuous improvement of the program.

The program outcomes (POs) designed by National Board of Accreditation (NBA), India for undergraduate engineering programs were meticulously designed to stipulate that the engineering curriculum must impart knowledge, skills, attitude within a graduate through the period of engineering education. The program outcomes have been laid out by NBA, India to lay ground rules for educational policies, institutional policies, curriculum design and implementation in engineering education. Thus, the educational institutions are obligated to explore their possibilities to impart skills to an engineering graduate in designing and implementing an engineering program. The accreditation agencies National Board of Accreditation (NBA), National Assessment and Accreditation Council (NAAC) for technical programs/institution are highly focusing on program assessments and usage of assessment results for continuous improvement.

A. Institutional Committees for Continuous Quality Improvement
Every educational institution should have a department level committee for academic auditing to support continuous evaluation, assessment and improvements of educational programs offered in the department. The Program Assessment and Quality Improvement (PAQI) Committee will act as a subcommittee of IQAC. It may operate on "Plan, Do, Check, Act (PDCA)" philosophy or any other similar model may be used.

PDCA (plan-do-check-act) cycle is an "iterative method that can be used in any system for quality control and continuous improvement of processes and/or products". The major activities of program assessment cycle with PDCA approach can be categorized as follows.

Plan (Plan Phase of PDCA cycle)- For each educational program, planning per assessment cycle involves setting the goals to be achieved, determining objectives, estimating required resources, developing execution plans, defining roles and responsibilities, facilitate meetings with faculty members, industry, advisory board, expert members etc.

Analyze (Check Phase of PDCA cycle) - For each educational program, analysing per assessment cycle involves determining appropriate assessment models $\&$ measures, determining components to be measured, collecting reliable evidence, performing assessment, interpreting assessment results to identify the underachievements.

Evaluate (Check Phase of PDCA cycle) - For each educational program, evaluating per assessment cycle involves identifying causes for remarkable deviations from the quality improvement plans, establishing status with respect to vision/mission of the department/institution.

Report (Act Phase of PDCA cycle) - For each educational program, reporting per assessment cycle involves providing timely feedback to redirect efforts for improved teaching-learning process, providing accountability to all the activities in department/institution, generating customized reports for stakeholders involving results of assessment and accomplishments of the program, communicating reports to stakeholders to inform impact and contributions of the program, showcasing quality of the program/institution.

Improve (Act Phase of PDCA cycle)- Utilize the assessment and evaluation reports effectively to 
review educational program, provide feedback on the program, evaluate the program with respect to the department vision and mission, provide suggestions/ recommendations for improvement of the program, establish/modernize of resources for the program/ department/institution, prepare strategic plans for the program/department/institution, revise vision, mission, objectives and outcomes of the program/department/institution.

One of the activities of PAQI committee is program assessment and evaluation for supporting CQI. There are various assessment models and methods developed for measuring the achievements and accomplishments of an educational program. The assessment models and methods adapted by an educational institution majorly depend upon their evaluation system in place, assumptions and beliefs. Any assessment model shall be authentic, valid and reliable. All the assessment methods are to ultimately provide operational excellence and high-value education to students. A good assessment plan involves evidential data representing both

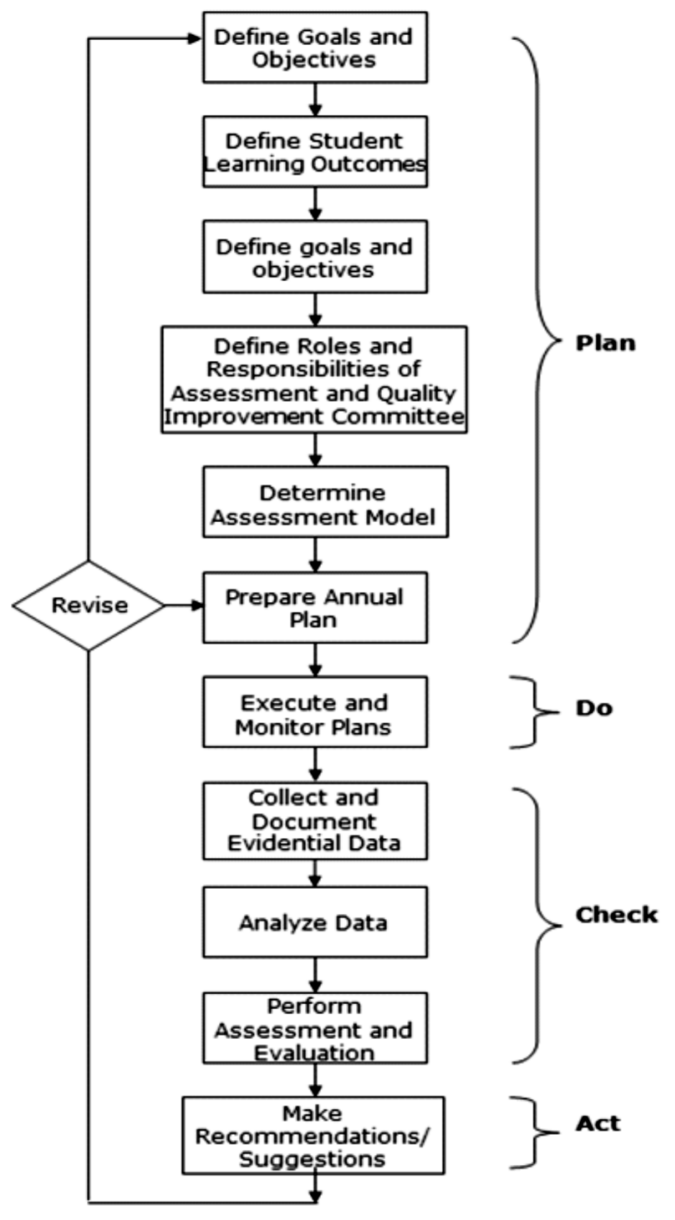

Fig. 1 : Program Assessment Lifecycle quantitative and qualitative information and data collection methods include formal and informal methods, direct and indirect methods. Evaluation by external experts supports a fresh eyes approach to provide a new and powerful perspective on the objects of assessment. Figure 1 shows program assessment lifecycle.

Assessment is a process that involves obtaining reliable information concerning the students' commands (objectives, knowledge, aptitudes, skills, behaviours, etc.), establishing judgments of value (acceptable, suitable, good, good enough, etc.) and making decisions (to accept, to pass, to recommend, to promote, to release, to recognize, etc.) (Contreras 2004).

\section{A. Assessment Tools}

Assessment tools are activities where students represent/express their learning. Assessment tools allow course instructors to collect evidence of students' learning levels. The tools for assessing students' performance continuum can be categorized into two types - tools that support direct and indirect methods of assessment. The direct assessment tools include written/oral exams, capstone projects, assignments, quizzes, portfolios etc. The indirect assessment tools include grades/CGPAs, graduation rates, student progression in the program, student progression to advanced degrees, placement statistics etc.

Indirect assessment tools are those activities which support assessment only through opinions of the assessor/stakeholder. Resources and services of an educational institution is assessed using indirect assessment tools whereas outcomes and objectives are measured using direct and indirect assessment tools. The opinions of stakeholders are gathered through surveys using questionnaires with open-ended and close-ended questions. Survey shall be conducted to gather opinions of stakeholders on resources, services or outcomes. Survey may also be conducted to gather a nip of students' experience through their educational program, capstone projects, internships, industrial visits, training programs etc. Opinions of departmental advisory board/industry advisory board on the effectiveness of the curriculum are also an example for indirect assessment. Indirect methods of outcomes assessment helps in the development of resources and revision of curriculum and instruction delivery. After collecting opinions of stakeholders through surveys, evidence must be analysed and 
strengths and weaknesses must be summarized and properly documented. Further, this assessment results shall be utilized for effective strategic planning.

\section{Benefits of Assessment}

The major benefits of program assessment for some of the stakeholders are as follows.

Students - To experience superior learning, explore individual talents, develop skills, experience trends in industry and society, become industry ready with competent curriculum etc.

Faculty - To assess their efforts, build self-morale, improve teaching/learning process, capacity building, use innovative teaching methods, improve student evaluation system, contribute to curricular reforms, self-analyze training needs, adapt to technological trends etc.

Educational Program - To evaluate the status, guide improvements/ future plans, guide curricular reforms, deliver skilled workforce etc.

Department - To establish performance indicators, identify critical issues, identify opportunities to improve services, monitor the progress, evaluate the status, demonstrate success, guide strategic planning, direct the efforts in proper trend, grab external funding, establish/modernize resources, attain accreditations, acquire memorandum of understandings etc.

Institution - To monitor quality, judge progress/ achievements/accomplishments, evaluate the status, demonstrate achievements, guide strategic planning, establish/modernize resources, attain accreditations, acquire memorandum of understandings, grab external funding, revise/improvise institutional policies/regulations, plan budgeting, risk management, develop competency to endure industry push, become self-sustainable, demonstrate commitment to stakeholders etc.

Industry - To comprehend the quality of the students for potential employment, acquire memorandum of understandings, recruit skilled professionals, work in close coordination with educational institutions to provide demand-driven curricula etc.

Government/Society - To assess quality of educational institutions, skilled workforce, development of educational system, reforms to educational policies etc.

\section{Literature Survey}

Outcome assessment is important so as to ensure the accountability of quality and success of an educational program (Carelli J, 2019). The outcome assessment implies that the educational program being offered is measured, analyzed and well documented to support continuous quality improvement

The results of survey performed to assess the impact of outcome based education in India are encouraging, showcasing that management, faculty and students are motivated towards outcome based education in engineering programs (Jadhav M.R. et al, 2020).

Models have been proposed for mapping course outcomes and program outcomes and generate attainment of outcomes Authors in (Admuthe LS et al., 2016, Sudheer K. et al., 2016). The attainment of outcomes support to develop an action plan at course and program level for improvement of curriculum and teaching-learning process. The proposed models did not present a view on how to develop action plan (Admuthe LS et al., 2016). Also, the method for determining strength of correlation between course outcomes and program outcomes was subjective i.e., strength is determined by observing curriculum and program outcomes (Admuthe LS et al., 2016).

Inclusion of a credit-based weight factor to the calculation of program outcome attainment supports a weighted average method of outcome attainment (Subbaraman S et al., 2016). This method allows to consider the individual contribution of curriculum components to achieve program outcomes.

The outcome mapping, assessment and documenting process is a complex and tedious process. Individual student learning outcome assessment is near to impossible to perform manually. A model for automation highly helps faculty and students to have greater insights into the teachinglearning process (Rajak etal., 2018).

A method called as term mapping has been presented for mapping course and program outcomes (Kulkarni V.A et al., 2017). It has been proposed to maintain a CO-PO mapping and attainment booklet for monitoring the continuous improvement of course 
outcomes. Authors made a concluding statement that their students have adapted well for the concept of CO-PO mapping and attainment booklet and the booklet was useful for identifying curriculum gaps.

\section{Assessment of Outcomes}

This section presents an efficient model for computing course and program outcome attainments. Academic assessment of students' achievements is performed by measuring Student learning outcomes (SLOs) at the end of each course (course outcomes $\mathrm{COs}$ ) and at the end of graduation (program outcomes - POs). For COs, data collection cycle repeats biannually and assessment cycle repeats annually. For program outcomes, data collection and assessment cycle repeats annually.

\begin{tabular}{|l|l|c|c|l|l|l|}
\hline S. No. & Topic & $\begin{array}{c}\text { No. of class } \\
\text { hours } \\
\text { required }\end{array}$ & $\begin{array}{c}\text { Teaching aids/ } \\
\text { ICT tools/ } \\
\text { Innovative } \\
\text { teaching methods }\end{array}$ & $\begin{array}{c}\text { Learning } \\
\text { Resources }\end{array}$ & $\begin{array}{c}\text { Course } \\
\text { Outcome } \\
\text { Mapped }\end{array}$ & $\begin{array}{c}\text { Program } \\
\text { Outcome } \\
\text { Mapped }\end{array}$ \\
\hline & & & & & \\
\hline & & & & & \\
\hline
\end{tabular}

Fig. 2 : Sample Template of a Macro Lesson Plan for a Course

Teaching a course is a three phase process Planning, Implementation and Assessment. The planning phase for a course begins by framing the syllabus, objectives, outcomes and determining assessment tools. The syllabus, objectives, outcomes and assessment tools for a course may be set individually by instructor or by university as part of regulations. Once syllabus and outcomes for a course are available, instructor has to start planning on how to implement the course and on how to assess student achievements in the course. The planning by the instructor begins with a macro lesson plan. A macro lesson plan provides a roadmap on how the instructor plans on achieving the course objectives. A macro lesson plan provides a high-level description of the course contents, their break down structure, timeline etc. Such a lesson plan would clearly and crisply provide highlights on the flexible plan to implement the course.

A traditional macro lesson plan prepared in engineering education included the following components of concern - topic title \& description, planned number of contact hours to cover topic, teaching aids/ICT tools, and learning resources. But, in order to support course/program outcome assessment, lesson plan must also include course outcome(s) mapped, key performance indicator(s) mapped, program outcome(s) mapped for each topic. Figure 2 shows sample template for a macro lesson plan that needs to be prepared to support course/program outcome assessment. Learning objectives shall be framed for each module of the course. Considering a one-to-many model of CO-PO mapping, granularity of the topic break down structure must be in such a way so as to uniquely map a sub-topic to one program outcome.

To the macro lesson plan of a course, instructor may include for each topic, how he/she plans to incorporate various teaching aids, ICT tools, activities and innovative teaching methods into class room teaching. Also, for each module, course instructor may include how he plans to support diversity of student intellect. For each topic, practice questions to support slow learners and assignments to support advanced learners may be included in macro lesson plan. Such a lesson plan acts as a roadmap with teaching hints on how instructor envisions on teaching the course.

Before beginning the course, instructor determines assessment tools for achieving COs and prepares a course assessment plan. The same is showcased to students and PAQI committee. The direct assessment tools may include written examinations (internal or end semester), oral examinations (internal or end semester), and assignments (case study, mini-project, literature survey etc). Each of the direct assessment tools must be assigned a weightage signifying on how much of contribution it makes to total outcome assessment.

\begin{tabular}{|c|c|c|}
\hline \multicolumn{3}{|c|}{ Course $\boldsymbol{C}_{\boldsymbol{C}}$} \\
\hline $\begin{array}{c}\text { Course } \\
\text { Outcome }\end{array}$ & $\begin{array}{c}\text { Assessment } \\
\text { Tools }\end{array}$ & $\begin{array}{c}\text { Target } \\
\text { Attainment (\%) }\end{array}$ \\
\hline $\mathrm{CO}_{1}$ & $\mathrm{E}_{\mathrm{a}}, \mathrm{E}_{\mathrm{d}}$ & TCOAtt $_{1}$ \\
\hline $\mathrm{CO}_{2}$ & $\mathrm{E}_{\mathrm{c}}, \mathrm{E}_{\mathrm{f}}, \mathrm{E}_{\mathrm{b}}$ & $\mathrm{TCOAtt}_{2}$ \\
\hline$\cdot$ & $\cdot$ & $\cdot$ \\
$\cdot$ & $\cdot$ & $\cdot$ \\
$\cdot$ & $\cdot$ & $\cdot$ \\
\hline $\mathrm{CO}_{\mathrm{m}}$ & $\mathrm{E}_{\mathrm{b}}, \mathrm{E}_{\mathrm{g}}, \mathrm{E}_{\mathrm{a}}$ & TCOAtt $_{\mathrm{m}}$ \\
\hline
\end{tabular}

Fig. 3 : Sample Template for Documenting Course Outcomes, Target Attainments and Assessment Tools for a Course 
The internal examinations (written examinations, oral examinations, quizzes etc) may be considered for $10 \%$ to $30 \%$ of contribution to total outcome assessment whereas end semester examinations may be considered for $65 \%$ to $85 \%$. If internal assessment tools include assignments, mini-project, literature review, case study etc which elevate higher order thinking skills and needs students to put substantial effort to complete the task, then the weightage of internal examinations shall be increased relatively. The indirect assessment tools like course end survey, feedback from students on guest lectures/workshops/training programs conducted for teaching part of the course etc may be considered for $5 \%$ to $10 \%$ of contribution to total outcome assessment.

\begin{tabular}{|c|c|c|}
\hline \multicolumn{3}{|c|}{ Course $\boldsymbol{C}_{\boldsymbol{C}}$} \\
\hline $\begin{array}{c}\text { Type of } \\
\text { Assessment } \\
\text { Tool }\end{array}$ & $\begin{array}{c}\text { Assessment } \\
\text { Tool }\end{array}$ & $\begin{array}{c}\text { Contribution } \\
\text { towards total } \\
\text { assessment (\%) }\end{array}$ \\
\hline \multirow{4}{*}{ Direct } & $\mathrm{E}_{1}$ & $\mathrm{~W}_{\mathrm{E} 1}$ \\
\cline { 2 - 3 } & $\mathrm{E}_{2}$ & $\mathrm{~W}_{\mathrm{E} 2}$ \\
\cline { 2 - 3 } & $\cdot$ & $\cdot$ \\
\cline { 2 - 3 } & $\cdot$ & $\cdot$ \\
\hline Indirect & $\mathrm{E}_{\mathrm{n}}$ & $\mathrm{W}_{\mathrm{En}}$ \\
\hline
\end{tabular}

Fig. 4 : Sample Template for Documenting Assessment Tools and Significance for a Course
Finally, course instructor shall set target outcome attainments for COs. Targets are set for each course outcome of course individually.

The target course outcome attainments shall be set based on the performance of past batch of students in this course, the complexity of course content, complexity of direct assessment tools, innovative teaching methodologies planned to adopt, guest lectures/ workshops/training programs planned to teach part of the course etc. Figures 3, 4 show sample templates for documenting COs, target attainments, assessment tools considered for achieving Os and their significance in course CC.

The instructor then implements course as per the set plans to achieve targets, conducts assessment tests and documents the evidential data. Figure 5 shows sample template for maintaining students' achievements in the course through direct assessment tools.

At the end of course, a course end survey shall be taken from students where students perform selfassessment of their learning levels, enhanced abilities and achievements after the course in terms of knowledge, skills and attitude. The students' learning experiences through the course can also be surveyed through personal interactions to improvise the implementation of course through next batch of

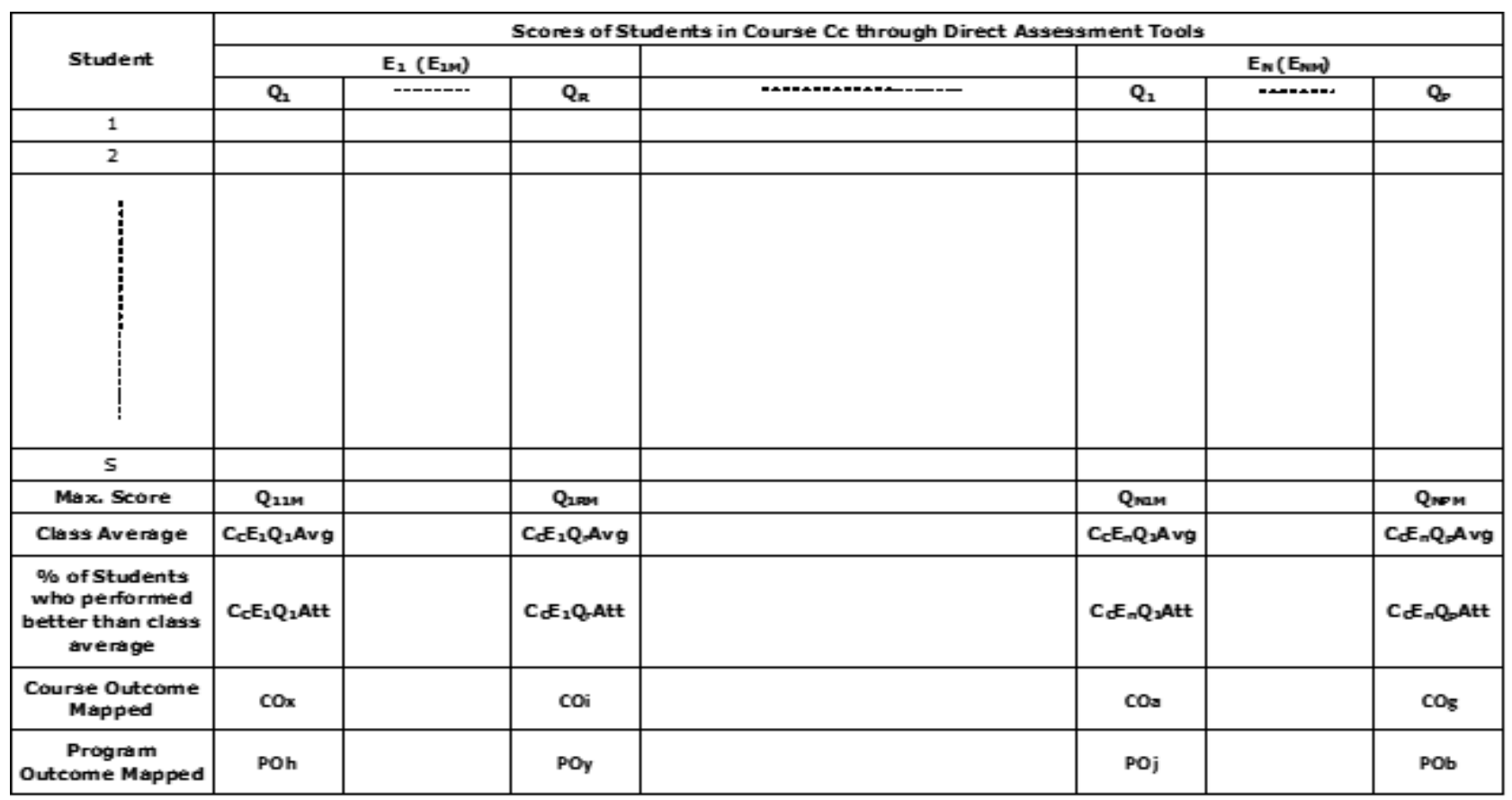

Fig. 5 : Sample Template for Documenting Direct Assessment Data for a Course 
students. Finally, instructor has to assess performance of students in the course in terms of attainment of COs and POs.

\section{A. Course Outcomes Assessment}

The attainment of individual COs of course $C_{C}$ through direct assessment tools can be assessed as follows. Let $\mathrm{C}_{\mathrm{C}} \mathrm{E}_{\mathrm{e}} \mathrm{Q}_{\mathrm{a}} \mathrm{Avg}$ represent class average of students who attempted problem $\mathrm{Qq}$ from direct assessment tool Ee. Let $\mathrm{C}_{\mathrm{C}} \mathrm{E}_{\mathrm{e}} \mathrm{Q}_{\mathrm{a}} \mathrm{Att}$ represent percentage of students who attempted problem- Qq from direct assessment tool $\mathrm{Ee}$ and achieved more than class average i.e., more than $\mathrm{C}_{\mathrm{C}} \mathrm{E}_{\mathrm{e}} \mathrm{Q}_{\mathrm{q}} \mathrm{Avg}$.

The attainment of an individual course outcome $\mathrm{CO}_{C O}$ through direct assessment tool $\mathrm{E}_{\mathrm{e}}$ can be assessed as average percentage of attainment of $\mathrm{CO}_{C O}$ from direct assessment tool Ee.

$$
C_{c} \mathrm{CO}_{c o} E_{e} A t t=A v e r a g e\left(C_{c} E_{e} Q_{q} A t t\right) \ldots E q(1)
$$

where any problem $Q_{q}$ from direct assessment tool $E_{e}$ is mapped to course outcome $C O_{C O}$.

The weighted attainment of an individual course outcome $\mathrm{CO}_{C O}$ through all direct assessment tools can $C_{C} C O_{C O}$ DirAtt $=\sum_{i=1}^{N}\left(C_{C} C O_{C O} E_{i} A t t \times \frac{W_{E i}}{100}\right) \ldots E q(2)$

The attainment of an individual course outcome $C O_{C O}$ through direct assessment tool $E_{e}$ can be assessed as average percentage of attainment of $C O_{C O}$ from direct assessment tool $E_{\text {o }}$.

$$
C_{C} C O_{C O} I n d A t t=C_{C} C O_{C O} I A t t \times \frac{W_{E I N D}}{100} \ldots E q(3)
$$

where $W_{E I N D}$ represents ratio of contribution of indirect assessment tool towards total assessment, $\mathrm{C}_{C} \mathrm{CO}_{\mathrm{CO}} \mathrm{IAtt}$ represents attainment of course outcome $\mathrm{CO}_{C O}$ through indirect assessment tool.

Figure 6 shows sample template for representing COs and their attainments in course $C_{c}$ through direct and indirect assessment tool.

\begin{tabular}{|c|c|c|c|c|}
\hline \multirow[b]{3}{*}{$\begin{array}{c}\text { Course } \\
\text { Outcome }\end{array}$} & \multicolumn{2}{|r|}{ Course $C_{C}$} & \multirow{3}{*}{\begin{tabular}{|c|}
$\begin{array}{c}\text { Weighted } \\
\text { Attainment } \\
\text { of CO from } \\
\text { Direct } \\
\text { Assessment } \\
(\%)\end{array}$ \\
\end{tabular}} & \multirow{3}{*}{$\begin{array}{c}\text { Weighted } \\
\text { Attainment } \\
\text { of CO from } \\
\text { Indirect } \\
\text { Assessment } \\
(\%)\end{array}$} \\
\hline & \multicolumn{2}{|c|}{ Direct Assessment Tool (\%) } & & \\
\hline & $\mathbf{E}_{1}$ & $\mathbf{E}_{N}$ & & \\
\hline $\mathrm{CO}_{1}$ & $\left|\mathrm{C}_{\mathrm{C}} \mathrm{CO}_{1} \mathrm{E}_{1} \mathrm{Att}\right|$ & $\left|\mathrm{C}_{\mathrm{C}} \mathrm{CO}_{1} \mathrm{E}_{\mathrm{N}} \mathrm{Att}\right|$ & $\mathrm{C}_{\mathrm{C}} \mathrm{CO}_{1}$ DirAtt & $\mathrm{C}_{\mathrm{C}} \mathrm{CO}_{1}$ IndAtt \\
\hline . & & & ${ }^{\circ}$ & \\
\hline $\mathrm{CO}_{\mathrm{m}}$ & $\mathrm{C}_{\mathrm{C}} \mathrm{CO}_{\mathrm{m}} \mathrm{E}_{1} \mathrm{Att}$ & $\mathrm{C}_{\mathrm{C}} \mathrm{CO}_{\mathrm{m}} \mathrm{E}_{\mathrm{N}} \mathrm{Att}$ & $\mathrm{C}_{\mathrm{C}} \mathrm{CO}_{\mathrm{m}}$ DirAtt & $\mathrm{C}_{\mathrm{C}} \mathrm{CO}_{\mathrm{m}}$ IndAt \\
\hline
\end{tabular}

$$
C_{C} \mathrm{CO}_{C O}=C_{C} \mathrm{CO}_{C O} \text { DirAtt }+C_{C} \mathrm{CO}_{C O} \operatorname{IndAtt} \ldots \mathrm{Eq}(4)
$$

Fig. 6 : Sample Template for Documenting Course Outcomes and Attainments for a Course

The final attainment of course outcome $C O_{C O}$ in the course $C_{c}$ will be

Once attainments of COs are assessed, the success or failure in achievement of targets in course shall be analyzed. The details of strategies followed by instructor in planning and implementing the course shall be documented so as to provide guidelines for improvements in course implementation for the next batch of students. If the set targets are not achieved,

\begin{tabular}{|l|c|c|c|}
\hline \multicolumn{4}{|c|}{ Course $\boldsymbol{C}_{\boldsymbol{C}}$} \\
\hline \multirow{2}{*}{ Items } & \multicolumn{3}{|c|}{ Course Outcomes } \\
\cline { 2 - 4 } & $\mathbf{C O}_{1}$ & $\ldots$ & $\mathbf{C O}_{\mathbf{m}}$ \\
\hline Target Attainment (\%) & $\mathrm{TCOAtt}_{1}$ & & $\mathrm{TCOAtt}_{\mathrm{m}}$ \\
\hline $\begin{array}{l}\text { Attainment Achieved } \\
(\%)\end{array}$ & $\mathrm{C}_{\mathrm{C} C \mathrm{CO}_{1}}$ & & $\mathrm{C}_{\mathrm{C} C \mathrm{C}_{\mathrm{m}}}$ \\
\hline $\begin{array}{l}\text { Whether Target } \\
\text { achieved? (Yes/No) }\end{array}$ & & & \\
\hline $\begin{array}{l}\text { Details of the strategies } \\
\text { followed in planning and } \\
\text { implementing the course }\end{array}$ & & & \\
\hline $\begin{array}{l}\text { Potential reasons for not } \\
\text { achieving target / } \\
\text { modification of target }\end{array}$ & & & \\
\hline $\begin{array}{l}\text { Suggestions for } \\
\text { improvement }\end{array}$ & & & \\
\hline
\end{tabular}

Fig. 7 : Sample Template for Documenting Course Outcome Assessment for a Course

reasons shall be analyzed and suggestions for improvement shall be documented. Figure 7 shows sample template for representing analysis of the final attainment of COs through direct and indirect assessment tools.

\section{A. Program Outcomes Assessment}


The assessment tools to evaluate students' achievements in the program may be decided by institution/university as part of the regulations/as part of outcome assessment policy. The attainment of POs from individual courses of the program is considered as direct attainment tool for the assessment of POs.

The indirect assessment tools typically include student exit survey, alumni survey (alumni students comprising of graduates from past three years) and employer survey. Student feedback from focus group on technical association activities, extra-curricular and co-curricular activities may also be considered as indirect assessment tools. Other indirect assessment tools may also be considered.

\begin{tabular}{|c|c|c|}
\hline \multicolumn{3}{|c|}{ Program P } \\
\hline $\begin{array}{c}\text { Type of } \\
\text { Assessment } \\
\text { Tool }\end{array}$ & Assessment Tool & $\begin{array}{c}\text { Contribution } \\
\text { towards total } \\
\text { assessment (\%) }\end{array}$ \\
\hline Direct & $\begin{array}{c}\text { Attainment from } \\
\text { individual courses }\end{array}$ & W $_{\text {DIR }}$ \\
\hline Indirect & $\begin{array}{c}\text { Attainment from } \\
\text { Surveys }\end{array}$ & W WIND \\
\hline
\end{tabular}

Fig. 8 : Sample Template for Documenting Assessment Tools and Significance for a Program

The attainment of POs from direct and indirect assessment tools must be assigned a weightage signifying on how much of contribution it makes to total assessment. The attainment from direct assessment tool may be considered for $70 \%$ to $80 \%$ of contribution to total assessment whereas the attainment from indirect assessment tool may be considered for $20 \%$ to $30 \%$. Figure 8 shows sample template for documenting the assessment tools considered and their significance for $\operatorname{program} P$.

The target attainments for POs are set for each program individually. The target attainments for current batch of students shall be set based on their prior to program performance, performance in first year academics, achievements of previous batches of students in the program, improvements in resources (physical, manual, laboratory, library, digital learning etc), new/revised/ amended academic regulations, best practices followed etc. Figure 9 shows sample template for documenting POs and their attainment targets for program $P$.

Not every course contributes at the same level

\begin{tabular}{|c|c|}
\hline \multicolumn{2}{|c|}{ Program P } \\
\hline Program Outcome & Target Attainment (\%) \\
\hline $\mathrm{PO}_{1}$ & TPOAtt $_{1}$ \\
\hline $\mathrm{PO}_{2}$ & TPOAtt $_{2}$ \\
\hline$\cdot$ & $\cdot$ \\
$\cdot$ & $\cdot$ \\
$\cdot$ & $\cdot$ \\
\hline $\mathrm{POP}$ & TPOAttP \\
\hline
\end{tabular}

Fig. 9 : Sample Template for Documenting Course Outcomes and Target Attainments for a Program

towards POs. Different courses will have different levels of knowledge, skills and attitude components. A course will meet a subset of POs with varying correlation levels between COs and POs. Figure 10 shows template for documenting the strength of correlation of a course towards POs. The strength correlation is most generally represented on a 3-point Likert scale with 3 representing highest correlation and 1 representing weakest correlation. ACO may not have correlation with a PO.

\begin{tabular}{|c|c|c|c|}
\hline \multicolumn{4}{|c|}{ Program P } \\
\hline \multirow{2}{*}{ Courses } & \multicolumn{3}{|c|}{ Program Outcomes } \\
\cline { 2 - 4 } & PO $_{1}$ & $\ldots \ldots$ & PO $_{\mathbf{P}}$ \\
\hline $\mathrm{C}_{1}$ & $\mathrm{CorC}_{11}$ & & CorC $_{1 \mathrm{P}}$ \\
\hline$\cdot$ & & & \\
$\cdot$ & & & \\
$\cdot \cdot$ & & & CorC \\
\hline $\mathrm{C}_{\mathrm{CP}}$ & CorC $_{\mathrm{C} 1}$ & & \\
\hline
\end{tabular}

Fig. 10 : Sample Template for

Documenting Correlation Mapping between Courses and Program Outcomes

\begin{tabular}{|c|c|}
\hline \multicolumn{2}{|c|}{ Program P } \\
\hline Course & Weightage (\%) \\
\hline $\mathrm{C}_{1}$ & $\mathrm{~W}_{\mathrm{C} 1}$ \\
\hline $\mathrm{C}_{2}$ & $\mathrm{~W}_{\mathrm{C} 2}$ \\
\hline$\cdot$ & $\cdot$ \\
$\cdot$ & $\cdot$ \\
$\cdot \cdot$ & $\cdot$ \\
\hline $\mathrm{C}_{\mathrm{r}}$ & $\mathrm{W}_{\mathrm{Cr}}$ \\
\hline
\end{tabular}

Fig. 11 : Sample Template for Documenting Courses in a Program and their contribution towards POs 
Courses in the program will be of varying complexity, and hence has varying number of lecture/practical hours and varying credits. Other parameters like number of students registered for course etc may also be considered. Hence, each course must be assigned a weightage to signify how much of contribution it makes to total program outcome assessment.

Figure 11 shows template for documenting courses in program $\mathrm{P}$ and their contribution towards POs. The weightage for each course $\mathrm{CC}$ towards POP considering number of credits assigned for $\mathrm{CC}$ can be computed as

$$
W_{c_{c}}=\frac{\text { No. of Credits for the course }}{\text { Total No. of Credits in the Program }} \times 100 \ldots E q \text { (5) }
$$

The attainment of a program outcome POPO from an individual course $\mathrm{CC}$ through direct assessment tools can be assessed as follows. Program outcome attainments may be assessed through course outcome attainments and CO-PO correlation mappings.

The attainment of a program outcome POPO from an individual course $\mathrm{CC}$ through direct assessment tools can be assessed as follows.

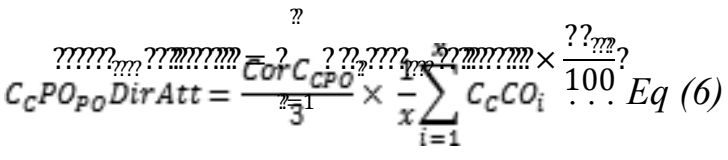

where $\mathrm{x}$ represents number of COs mapped to POPO, COi represents course outcome mapped to POPO, CCCOiDirAtt represents attainment of course outcome $\mathrm{CO}$ i in course $\mathrm{CC}$ through all direct assessment tools, CorCCPO represents level of correlation between course $\mathrm{CC}$ and program outcome POPO.

\begin{tabular}{|c|c|c|c|}
\hline \multicolumn{4}{|c|}{ Program P } \\
\hline \multirow{2}{*}{ Courses } & $\begin{array}{c}\text { Attainment of Program Outcomes } \\
\text { through individual courses in the } \\
\text { program (\%) }\end{array}$ \\
\cline { 2 - 4 } & PO $_{1}$ & $\ldots \ldots$ & PO $_{\mathrm{P}}$ \\
\hline $\mathrm{C}_{1}$ & $\mathrm{C}_{\mathrm{c}} \mathrm{PO}_{1}$ DirAtt & & $\mathrm{C}_{\mathrm{c}} \mathrm{PO}_{\mathrm{p}}$ DirAtt \\
\hline$\cdot$ & $\cdot$ & & $\cdot$ \\
$\cdot$ & $\cdot$ & & $\cdot$ \\
$\cdot \cdot$ & $\cdot$ & & $\cdot$ \\
\hline $\mathrm{C}_{\mathrm{r}}$ & $\mathrm{C}_{\mathrm{r}} \mathrm{PO}_{1}$ DirAtt & & $\mathrm{C}_{\mathrm{PPO}} \mathrm{PirAtt}$ \\
\hline
\end{tabular}

Fig. 12 : Sample Template for Documenting Program Outcome Attainments through Direct Assessment Tools
For each course $\mathrm{CC}$ in the program $\mathrm{P}$, the relevant program outcome attainments are calculated. Figure 12 shows sample template for documenting the courses in a program and program outcome attainments through individual courses.

The final attainment of program outcome POPO for the program $\mathrm{P}$ through all the courses in the program will be

$$
P P O_{P O} \text { DirAtt }=\sum_{i=1}^{r}\left(C_{i} P O_{P O} \text { DirAtt } \times \frac{W_{C i}}{100}\right) \ldots E q(7)
$$

where $r$ represents number of courses in the program $\mathrm{P}$, CiPOPODirAtt represents attainment of POPO in course $\mathrm{Ci}$ through direct assessment tools, WCi represents weightage of Course $\mathrm{C} i$ in program $\mathrm{P}$.

\begin{tabular}{|c|c|c|c|}
\hline \multicolumn{4}{|c|}{ Program P } \\
\hline \multirow{2}{*}{$\begin{array}{c}\text { Assessment } \\
\text { Method }\end{array}$} & Attainment of Program Outcomes (\%) \\
\cline { 2 - 4 } & PO $_{\mathbf{1}}$ & $\ldots \ldots$ & POP $_{\mathbf{P}}$ \\
\hline Direct & $\mathrm{PPO}_{1}$ DirAtt & & PPOPDirAtt \\
\hline Indirect & $\mathrm{PPO}_{1}$ IndirAtt & & PPOPIndirAtt \\
\hline $\begin{array}{c}\text { Average } \\
\text { Attainment of POs }\end{array}$ & $\mathrm{PPO}_{1}$ & & PPOP \\
\hline $\begin{array}{c}\text { Targeted } \\
\text { Attainment of POs }\end{array}$ & TPOAtt $_{1}$ & & TPOAttP \\
\hline
\end{tabular}

Fig. 13 : Sample Template for Documenting Program Outcome Attainments for a Program

The final attainment of program outcome POPO for program $\mathrm{P}$ in the program through indirect assessment tools will be +

$$
P P O_{P O} \text { IndirAtt }=\frac{\sum_{i=1}^{I N D R}\left(P P O_{P O} I_{\text {Ind } A t t}\right)}{I N D R} \ldots E q(8)
$$

where INDR represents number of indirect assessment tools, PPOPOIndAtti is attainment of program outcome POPO in the program through indirect assessment tool IndAtti.

The final attainment of program outcome POPO for program $\mathrm{P}$ through direct and indirect assessment tools will be

$$
\begin{array}{r}
P P O_{P O}=P P O_{P O} \text { DirAtt } \times \frac{W_{D I R}}{100}+P P O_{P O} \text { IndirAtt } \\
\times \frac{W_{E I N D}}{100} \\
\ldots E q(9)
\end{array}
$$

where PPOPODirAtt and PPOPOIndAtt represent attainment of $\mathrm{POPO}$ in program $\mathrm{P}$ through direct and indirect assessment tools respectively, WDIR and WEIND represent weightages of direct and indirect assessment tools respectively. Figure 13 shows 
sample template for documenting program outcome attainments in a program.

All the outcome attainment values in the above presented model are in percentages (100-point scale). As per the new NBA SAR, the outcome attainments are to be presented on a 3-point Likert scale. The following method may be used for converting outcome attainments values from percentages to a 3point Likert scale. For example, program outcome attainments in Figure 13 can be presented on a 3-point scale as

IfPPOi is $>75 \%, 3$ _Point_PPOi $=3$

Else If PPOi is $>50 \%$ and $<=75 \%, 3$ _Point_PPOi $=2$

Else IfPPOi is $<50 \%, 3 \_$Point_PPOi $=1$

The outcome attainment percentages can be normalized to a 3-point scale by using min-max normalization. For example, program outcome attainments in Figure 13 can be normalized to a 3point scale as

$$
\text { 3_Point } P P O_{i}=\left(\frac{P P O_{i}}{100} \times 2\right)+1 \ldots E q(10)
$$

\section{Program Specific Outcomes Assessment}

Program Specific Outcomes (PSOs) attainments shall be assessed and documented in the same model of PO assessment. Assessing POs provides a holistic view of the curriculum, instruction delivery and quality of education provided in the program whereas assessing PSOs provides insights into the core discipline of the program i.e., POs and PSOs assessment provides insights into the breadth and depth of the discipline of the program respectively.

\section{Case Study of Outcome Assessment}

A case study is presented for demonstrating the course outcome and program outcome attainment using the proposed model. We have applied the proposed model for computing program outcome attainments of 2016-20 B.Tech. (Computer Science and Engineering) program. To demonstrate computing of course outcome attainment using proposed model, a case study is presented with computer organization course.

Figure 14 shows COs, targeted attainments and selected assessment tools (direct and indirect) for the computer organization course. Figure 15 shows

\begin{tabular}{|l|c|c|}
\hline \multicolumn{3}{|c|}{ Course: Computer Organization } \\
\hline \multicolumn{1}{|c|}{ Course Outcome } & Assessment Tools & $\begin{array}{c}\text { Target } \\
\text { Attainment } \\
\text { (\%) }\end{array}$ \\
\hline $\begin{array}{l}\text { CO1: Analyze computer } \\
\text { arithmetic algorithms for fixed - } \\
\text { point and floating-point binary } \\
\text { operations. }\end{array}$ & $\begin{array}{c}\text { Mid semester } \\
\text { exam, End semester } \\
\text { exam, Course end } \\
\text { survey }\end{array}$ & 70 \\
\hline $\begin{array}{l}\text { CO2: Analyze the architecture, } \\
\text { organization and functions of the } \\
\text { components of a digital computer. }\end{array}$ & $\begin{array}{c}\text { Mid semester } \\
\text { exam, End semester } \\
\text { exam, Course end } \\
\text { survey }\end{array}$ & 70 \\
\hline $\begin{array}{l}\text { CO3: Design digital circuits for } \\
\text { the given functional description } \\
\text { of microoperations and memory } \\
\text { elements. }\end{array}$ & $\begin{array}{c}\text { Mid semester } \\
\text { exam, Assignment, } \\
\text { End semester exam, } \\
\text { Course end survey }\end{array}$ & 65 \\
\hline $\begin{array}{l}\text { CO4: Investigate the performance } \\
\text { of memory systems, I/O systems, } \\
\text { pipelined processors and } \\
\text { multiprocessors to evaluate the } \\
\text { cost-performance trade-offs. }\end{array}$ & $\begin{array}{c}\text { Mid semester } \\
\text { exam, Assignment, } \\
\text { End semester exam, } \\
\text { Course end survey }\end{array}$ & 65 \\
\hline
\end{tabular}

Fig. 14 : Documented COs, Target Attainments and Assessment Tools for Computer Organization Course

\begin{tabular}{|c|c|c|}
\hline \multicolumn{3}{|c|}{ Course: Computer Organization } \\
\hline $\begin{array}{c}\text { Type of } \\
\text { Assessment } \\
\text { Tool }\end{array}$ & Assessment Tool & $\begin{array}{c}\text { Contribution } \\
\text { towards total } \\
\text { assessment (\%) }\end{array}$ \\
\hline \multirow{3}{*}{ Direct } & Mid semester exam & 24 \\
\cline { 2 - 3 } & Assignment & 8 \\
\cline { 2 - 3 } & End semester exam & 48 \\
\hline Indirect & Course end survey & 20 \\
\hline
\end{tabular}

Fig. 15 : Documented Assessment Tools and their Significance for Computer Organization Course

assessment tools (direct and indirect) and the assigned significance for each assessment tool. The significance is assigned as $80 \%$ for all direct assessment tools combined. Each direct assessment

\begin{tabular}{|c|c|c|c|c|c|}
\hline \multicolumn{5}{|c|}{ Course: Computer Organization } \\
\hline \multirow{2}{*}{$\begin{array}{c}\text { Course } \\
\text { Outcome }\end{array}$} & $\begin{array}{c}\text { Direct Assessment Tool (\%) } \\
\text { semester } \\
\text { exam }\end{array}$ & Assignment & $\begin{array}{c}\text { Weighted } \\
\text { Attainment } \\
\text { of Co from } \\
\text { semester } \\
\text { exam }\end{array}$ & $\begin{array}{c}\text { Weighted } \\
\text { Attainment } \\
\text { of CO } \\
\text { from } \\
\text { Assesment } \\
\mathbf{( \% )}\end{array}$ & $\begin{array}{c}\text { Indirect } \\
\text { Assessment } \\
(\%)\end{array}$ \\
\hline $\mathrm{CO}_{1}$ & 89 & - & 81 & 65.6 & 20 \\
\hline $\mathrm{CO}_{2}$ & 91 & - & 85 & 68.1 & 20 \\
\hline $\mathrm{CO}_{3}$ & 82 & 86 & 75 & 62.5 & 18 \\
\hline $\mathrm{CO}_{4}$ & 84 & 79 & 81 & 65.4 & 19 \\
\hline
\end{tabular}

Fig. 16 : Documented COs and Attainments for Computer Organization Course 
tool is given significance based on its contribution to the total marks of the course. The significance of indirect assessment tool is taken as $20 \%$.

\begin{tabular}{|c|c|c|c|c|}
\hline \multicolumn{5}{|c|}{ Course: Computer Organization } \\
\hline \multirow{2}{*}{ Items } & \multicolumn{4}{|c|}{ Course Outcomes } \\
\hline & $\mathrm{CO}_{1}$ & $\mathrm{CO}_{2}$ & $\mathrm{CO}_{3}$ & $\mathrm{CO}_{4}$ \\
\hline Target Attainment (\%) & 70 & 70 & 65 & 65 \\
\hline $\begin{array}{l}\text { Attainment Achieved } \\
(\%)\end{array}$ & 85.6 & 88.1 & 80.5 & 84.4 \\
\hline $\begin{array}{l}\text { Whether Target } \\
\text { achieved? (Yes/No) }\end{array}$ & Yes & Yes & Yes & Yes \\
\hline $\begin{array}{l}\text { Details of the strategies } \\
\text { followed in planning } \\
\text { and implementing the } \\
\text { course }\end{array}$ & \multicolumn{4}{|c|}{$\begin{array}{l}\text { O ICT tools are used to teach topics } \\
\text { O Innovative teaching method s Cooperative } \\
\text { learning, POGIL are used to create interest } \\
\text { in students in classroom activities. } \\
\text { O Students are assigned tasks of presenting } \\
\text { talks on latest technologies like SSDs, etc } \\
\text { as classroom activity to promote interaction } \\
\text { between students. }\end{array}$} \\
\hline $\begin{array}{l}\text { Potential reasons for } \\
\text { not achieving target / } \\
\text { modification of target }\end{array}$ & - & - & - & - \\
\hline $\begin{array}{l}\text { Suggestions for } \\
\text { improvement }\end{array}$ & \multicolumn{4}{|c|}{$\begin{array}{l}\text { More diverse assignments may be given to } \\
\text { students to motivate them for improving their } \\
\text { design skills. }\end{array}$} \\
\hline
\end{tabular}

Fig. 17 : Documented CO Assessment for Computer Organization Course

\begin{tabular}{|c|c|c|}
\hline \multicolumn{3}{|c|}{ Program: B.Tech. (CSE) } \\
\hline $\begin{array}{c}\text { Type of } \\
\text { Assessment } \\
\text { Tool }\end{array}$ & Assessment Tool & $\begin{array}{c}\text { Contribution } \\
\text { towards total } \\
\text { assessment (\%) }\end{array}$ \\
\hline Direct & $\begin{array}{c}\text { Attainment from } \\
\text { individual courses }\end{array}$ & $80 \%$ \\
\hline Indirect & $\begin{array}{c}\text { Attainment from } \\
\text { Surveys }\end{array}$ & $15 \%$ \\
\cline { 2 - 3 } & $\begin{array}{c}\text { Attainment from } \\
\text { Co-curricular/ } \\
\text { Extra-curricular } \\
\text { Activities }\end{array}$ & $5 \%$ \\
\hline
\end{tabular}

Fig. 18 : Documented Assessment Tools and Significance

\begin{tabular}{|c|c|c|c|c|c|c|c|c|c|c|c|c|c|}
\hline \multicolumn{14}{|c|}{ Program: B.Tech. (CSE) } \\
\hline \multirow{2}{*}{ Courses } & \multicolumn{13}{|c|}{ Program Outcomes } \\
\hline & $\mathrm{PO}_{1}$ & $\mathrm{PO}_{2}$ & $\mathrm{PO}_{3}$ & $\mathbf{P O}_{4}$ & $\mathrm{PO}_{5}$ & & PO & & ${ }_{8} \mathbf{P C}$ & & $\mathbf{O}_{10}$ & $\mathbf{P O}_{11}$ & $\mathbf{P O}_{12}$ \\
\hline $\begin{array}{c}\text { Computer } \\
\text { Organization }\end{array}$ & 3 & 3 & 2 & - & - & - & - & - & & & - & - & - \\
\hline. & & & & & & & & & & & & & \\
\hline $\mathrm{Cr}$ & & & & & & & & & & & & & \\
\hline
\end{tabular}

Fig. 19 : Documented Correlation Mapping between Courses and POs
Figure 16 shows attainments of COs through direct and indirect assessment tools. Figure 17 shows outcome assessment for the computer organization course.

The remaining part of this section presents computing final PO attainments of B.Tech. (CSE) program. Figure 18 shows direct and indirect assessment tools and their significance we have chosen for computing PO attainments. $80 \%$ of PO assessment is contributed from direct assessment and 20\% from indirect assessment. Direct PO assessment comes from attainment of individual courses offered in the program. Indirect PO assessment comes from attainment from surveys (exit survey, alumni survey, employer survey) and attainment from cocurricular/extra-curricular activities conducted for students during the program.

\begin{tabular}{|c|c|}
\hline \multicolumn{2}{|c|}{ Program: B.Tech. (CSE) } \\
\hline Course & $\begin{array}{c}\text { Weightage (\%) } \\
\text { Credits for course/Total } \\
\text { credits for program x 100 }\end{array}$ \\
\hline Computer Organization & $3 / 180 \times 100=1.66$ \\
\hline$\cdot$ & $\cdot$ \\
$\cdot$ & $\cdot$ \\
\hline $\mathrm{Cr}$ & $\cdot$ \\
\hline
\end{tabular}

Fig. 20 : Documented Courses and their contribution towards POs

\begin{tabular}{|c|c|c|c|c|c|c|c|c|c|c|c|}
\hline \multicolumn{12}{|c|}{ Program: B.Tech. (CSE) } \\
\hline \multirow[t]{2}{*}{ Courses } & \multicolumn{11}{|c|}{$\begin{array}{l}\text { Attainment of Program Outcomes through } \\
\text { individual courses in the program }(\%)\end{array}$} \\
\hline & \begin{tabular}{|l|l|}
$\mathbf{P O}_{1}$ & $\mathbf{P O}_{2}$ \\
\end{tabular} & $\mathrm{PO}_{3}$ & & $\mathrm{PO}_{5}$ & & $\mathbf{P O}_{7}$ & & $\mathbf{P O}_{9}$ & $\mathbf{P O}_{1}$ & $\mathbf{P O}_{11}$ & $\mathbf{P O}_{12}$ \\
\hline $\begin{array}{l}\text { Computer } \\
\text { Organization }\end{array}$ & 84.684 .6 & 53.6 & - & - & - & - & - & - & - & - & - \\
\hline · & & & & & & & & & & & \\
\hline $\mathrm{Cr}$ & & & & & & & & & & & \\
\hline
\end{tabular}

Fig. 21 : Documented PO Attainments through Direct Assessment Tools

Figure 19 shows correlation mapping between courses and POs. Figure 20 shows courses and their contribution towards POs. The credits of the course are considered as the basis for defining contribution of courses towards POs. Figure 21 shows PO Attainments through direct assessment tools. Figure 22 shows final PO Attainments achieved for B.Tech. (CSE) program for students of batch 2015-19. Figure 


\begin{tabular}{|c|c|c|c|c|c|c|c|c|c|c|c|c|c|c|}
\hline \multicolumn{10}{|c|}{ Program: B.Tech. (CSE) } \\
\hline \multirow{2}{*}{ Courses } & \multicolumn{7}{|c|}{ Attainment of Program Outcomes (\%) } \\
\cline { 2 - 13 } & $\mathbf{P O}_{1}$ & $\mathbf{P O}_{2}$ & $\mathbf{P O}_{3}$ & $\mathbf{P O}_{4}$ & $\mathbf{P O}_{5}$ & $\mathbf{P O}_{6}$ & $\mathbf{P O}_{7}$ & $\mathbf{P O}_{8}$ & $\mathbf{P O}_{9}$ & $\mathbf{P O}_{10}$ & $\mathbf{P O}_{11}$ & $\mathbf{P O}_{12}$ \\
\hline Direct & 85 & 79 & 67 & 68 & 81 & 77 & 79 & 81 & 78 & 82 & 74 & 86 \\
\hline Indirect & 92 & 85 & 72 & 79 & 88 & 89 & 87 & 87 & 100 & 91 & 72 & 94 \\
\hline $\begin{array}{c}\text { Average } \\
\text { Attainment } \\
\text { of POs }\end{array}$ & 86.4 & 80.2 & 68 & 70.2 & 82.4 & 79.4 & 80.6 & 82.2 & 82.4 & 83.8 & 73.6 & 87.6 \\
\hline $\begin{array}{c}\text { Targeted } \\
\text { Attainment } \\
\text { of POs }\end{array}$ & 75 & 70 & 70 & 70 & 75 & 70 & 70 & 75 & 75 & 75 & 70 & 75 \\
\hline
\end{tabular}

Fig. 22 : Documented Final PO Attainments

\begin{tabular}{|c|c|c|c|c|c|c|c|c|c|c|c|c|}
\hline \multicolumn{7}{|c|}{ Program: B.Tech. (CSE) } \\
\hline \multirow{2}{*}{ Courses } & \multicolumn{7}{|c|}{ Attainment of Program Outcomes (\%) } \\
\cline { 2 - 10 } & $\mathbf{P O}_{1}$ & $\mathbf{P O}_{2}$ & $\mathbf{P O}_{3}$ & $\mathbf{P O}_{4}$ & $\mathbf{P O}_{5}$ & $\mathbf{P O}_{6}$ & $\mathbf{P O}_{7}$ & $\mathbf{P O}_{8}$ & $\mathbf{P O}_{9}$ & $\mathbf{P O}_{10}$ & $\mathbf{P O}_{11}$ & $\mathbf{P O}_{12}$ \\
\hline $\begin{array}{c}\text { Average } \\
\text { Attainment } \\
\text { of POs }\end{array}$ & 86.4 & 80.2 & 68 & 70.2 & 82.4 & 79.4 & 80.6 & 82.2 & 82.4 & 83.8 & 73.6 & 87.6 \\
\hline $\begin{array}{c}\text { Attainment } \\
\text { of POs on 3- } \\
\text { point scale }\end{array}$ & 3 & 3 & 2 & 2 & 3 & 3 & 3 & 3 & 3 & 3 & 2 & 3 \\
\hline
\end{tabular}

Fig. 23 : Documented Final PO Attainments on a 3-point Scale

23 shows final PO attainments achieved on a 3-point scale.

\section{Closing the Loop}

A continuous quality improvement process comprises of assessment and evaluation. ABET defines assessment and evaluation as follows.

Assessment is one or more processes that identify, collect, and prepare data to evaluate the attainment of student outcomes. Effective assessment uses relevant direct, indirect, quantitative and qualitative measures as appropriate to the outcome being measured. Appropriate sampling methods may be used as part of an assessment process.

Evaluation is one or more processes for interpreting the data and evidence accumulated through assessment processes. Evaluation determines the extent to which student outcomes are being attained. Evaluation results in decisions and actions regarding program improvement.

Closing the loop simply means using assessment results for program change and improvement (Evans C. 2013). Once the assessment results are available, the status of progress and achievement of targets needs to analyzed and documented for self-

\begin{tabular}{|l|c|c|c|}
\hline POs & $\begin{array}{c}\text { Target } \\
\text { Level }\end{array}$ & $\begin{array}{c}\text { Attainment } \\
\text { Level }\end{array}$ & \multicolumn{1}{c|}{ Observations } \\
\hline $\begin{array}{l}\text { PO1: } \\
\text { mathematics, science, engineering fundamentals, and an } \\
\text { engineering specialization to the solution of complex } \\
\text { engineering problems. }\end{array}$ \\
\hline PO1 & $\mathbf{7 5}$ & $\mathbf{8 6 . 4}$ & $\begin{array}{l}\text { The expected level of PO1 is } \\
\text { attained in most of the courses. For } \\
\text { courses Data Structures, Computer } \\
\text { Organization, Database } \\
\text { Management Systems, Computer } \\
\text { Vision, Machine Learning, the } \\
\text { attainment is below the expected } \\
\text { level. }\end{array}$ \\
\hline
\end{tabular}

On discussions with Faculty and Students, the reasons for low attainment were identified and the following actions were proposed/implemented:

1. PAQI committee has considered providing a tutorial hour for courses Data Structures, Computer Architecture \& Organization, Database Management Systems in the upcoming academic regulations.

2. Students are rendered to more practice in Data Structures Laboratory through online coding platforms to provide opportunity to students to apply their conceptual knowledge to solve complex engineering problems.

3. Cooperative Learning activities (one per module) were organized for Computer Organization course as pedagogical initiative to motivate students towards learning.

4. PAQI committee has considered including Image Processing course in the upcoming academic regulations to provide necessary prerequisite knowledge for Computer Vision course.

5. PAQI committee has considered creating digital content of lecture videos to support weak students for self -paced learning, revision of course content etc. The digital content will be create $d$ progressively in the time period of three years.

6. Statistical knowledge of students must be strengthened for improved learning in machine learning course.

\section{Fig. 24 : Sample Template for Documenting Action Taken Reports}

evaluation. Action plan shall be prepared for the upcoming academic year based on the evaluation report of previous academic year. Figure 24 shows a sample template for documenting program outcome attainments and action taken reports. The template is taken from NBA Self Assessment Report for engineering undergraduate program January 2016 manual (NBA SAR Jan 2016). The figure also shows a sample of actions taken for program outcomes in computer science engineering department. The proposed method gave more clear insights into the outcome attainments by considering various parameters like complexity of course, content of course etc. This helped in writing more specific action taken report and for planning actions to be taken for the upcoming batches. 


\section{Conclusions}

Student performance assessment is a continuous task in teaching-learning process where students are assigned a variety of tasks to execute and are keenly observed for their performance. An efficient model is proposed for course outcome and program assessment. The proposed model considers different parameters like strength of correlation between course outcome and program outcome, significance of course in the educational program etc for computing outcome assessment. By considering these parameters a more efficient assessment can be made. The proposed method gave more clear insights into the outcome attainments by considering various parameters like complexity of course, content of course etc. This helped in writing more specific action taken report and for planning actions to be taken for the upcoming batches. Further, the challenge is to frame a model for measuring individual student learning outcomes.

The program evaluation and assessment results must be properly utilized for continuous improvement of the program. The PAQI committee plays a crucial role in measuring the quality of education being provided in the institution and to establish policies, activity plans and execution plans for continuous quality improvement of the educational programs in the institution.

\section{References}

[1]A B E T A c c r e d i t a t i o n, https://www.abet.org/accreditation/, retrieved Oct 2019.

[2]Admuthe, L.S., Loni, D.Y. (2016) Course Outcome-Program Outcome Mapping Matrix \& Attainment-Issues and Model Based Solutions for Tier II Category, Journal of Engineering Education Transformations.

[3]AICTE Recommendations for Examination Reforms (2018), https://www.aicteindia.org/sites/default/files/ExaminationReform s.pdf, retrieved Jul 2019.

[4]Allen, M. J. (2004), Assessing Academic Programs in Higher Education. Bolton, MA: Anker Publishing Company.

[5] Carelli, J. (2019) Seeking ABET Accreditation: A
Case Study in Outcome Assessment. In Proceedings of International Conference on Frontiers in Education: Computer Science and Computer Engineering, 81-87.

[6]Contreras, E. (2004), Evaluation of University Learning, University Teaching, Orientations for Teacher Training, ICE, University of Oviedo, Oviedo, 129-152.

[7]Evans, C. (2013), Making Sense of Assessment Feedback in Higher Education, Review of Educational Research, 83(1), 70-120.

[8]Harmanani, H.M. (2017) An outcome-based assessment process for accrediting computing programmes, European Journal of Engineering Education, 42(6), 844-859.

[9]Huba, M. E., and Freed J. E. (2000), Learnercentered Assessment on College Campuses: Shifting the Focus from Teaching to Learning, Allyn \& Bacon, 160 Gould St., Needham Heights, MA02494.

[10]Jadhav, M.R., Kakade, A.B., Jagtap, S.R. and Patil, M.S., (2020) Impact assessment of outcome based approach in engineering education in India, Procedia Computer Science, 172, 791-796.

[11]Kulkarni, V.A., Ahuja, B.B. and Dhanvijay, M.R. (2017) CO-PO Mapping and Attainment Booklet for Tier-II Students with Rubrics Assessment, Journal of Engineering Education Transformations, 30(3), 28-34.

[12]NBA SAR National Board of Accreditation Self Assessment Report for Engineering Undergraduate Program, Jan 2016 , https://www.nbaind.org/Downloads/Documents, retrieved Oct 2019.

[13]Rajak, A., Shrivastava, A.K., Shrivastava, D.P. (2018) Automating Outcome Based Education for the Attainment of Course and Program Outcomes, In 2018 Fifth HCT Information Technology Trends (ITT) 373-376, IEEE.

[14]Subbaraman, S., Dharmadhikari, V.B. and Patil, B.G. (2016) Computing Attainment of Program Outcomes by Associating Credit Based Weight Factor of the Components of Curriculum, Journal of Engineering Education Transformations. 
[15]Sudheer, K., V. V. N. Sujit, N. V. G. Prasad, and K. Ravichand. (2016) A Novel Method of Learning Outcome Assessment in Outcome Based
Education, In 2016 IEEE 4th International Conference on MOOCs, Innovation and Technology in Education (MITE), 328-331, IEEE. 